\title{
The Earth Mourns: Interconnectedness of Yahweh, People and Land in Jeremiah 23:10 and 15
}

\author{
WiLhelM J WeSSELS (UNIVERSITY OF SOUTH AFRICA)
}

\begin{abstract}
According to Jeremiah 23:10 the land mourns because of the unethical behaviour of the religious leaders in Judean society. The example set by these leaders gives leeway to the people of Judah to follow suit. The article discusses the relationship between the actions of people in society and the effect of their behaviour on the land. I depart from the assumption that this reciprocal relational reliance is the result of a particular worldview in which there exists interconnectedness of the divine, the people relating to this divine entity and the land allotted to them. The view argued is that Jeremiah 23:10 reflects a particular worldview consisting of the conceptual structures HOLY/COMMON and PURE/IMPURE. Besides discussing the issue of the relationship between the divine, the people and the land in 23:10 and 15, I make some suggestions relevant to the ecological debate in society.
\end{abstract}

KEYWORDS: Mourn; land; unethical behaviour; curse; worldview; Jeremiah 23:10; adultery; evil

\section{A INTRODUCTION}

There has nowadays been some interest shown by scholars in engaging matters about ecology theologically. This is also true for the African continent where there is a developing interest in matters regarding ecology from a biblical perspective. ${ }^{1}$ This article is an attempt to make a modest contribution in this

* Submitted: 24/06/2020; peer-reviewed: 19/08/2020; accepted: 25/08/2020. Wilhelm J Wessels "The Earth Mourns: Interconnectedness of Yahweh, People and Land in Jeremiah 23:10 and 15," Old Testament Essays 33 no. 2 (2020): 306 - 322. DOI: https://doi.org/10.17159/2312-3621/2020/v33n2a9.

1 Some examples are Solomon Olusola Ademiluka, "An Ecological Interpretation of Leviticus 11-15 in an African (Nigerian) Context," Old Testament Essays 22, No. 3 (2009): 525-534; Schalk W. Van Heerden, "Taking Stock of Old Testament Scholarship on Environmental Issues in South Africa: Main Contributions and Challenges," Old Testament Essays 22, No. 3 (2009): 695-718; Kivatsi J. Kavusa, "Social Disorder and the Trauma of the Earth Community: Reading Hosea 4:1-3 in Light of Today's Crises," Old Testament Essays 29, No. 3 (2016): 481-501; Schalk W. Van Heerden, "Shades of Green - Grey? Towards an Ecological Interpretation of Jonah 4:6-11," Old Testament Essays 30, No. 2 (2017): 459-477; Kivatsi J. Kavusa, "An Eco-Theological interpretation of Proverbs 5:15-20 in the light of water crises experienced in presentday Africa," Old Testament Essays 30, No. 3 (2017): 707-724; Kivatsi J. Kavusa, "Creation made into חזכְָמָה: The eco-theological appraisal of the intrinsic worth of nature 
regard to the current debate. In 2002 Katherine Hayes wrote a monograph entitled "The Earth Mourns": Prophetic Metaphor and Oral Aesthetic, in which she discusses various prophetic texts employing the use of the verb 'äbal "to mourn."2 One of the uses of the verb appears in Jeremiah 23:10. This verse forms part of the bigger section (23:9-15) and is one of the oracles that form part of the cycle of oracles on the prophets in 23:9-40. This passage is of interest for this article and justifies further scrutiny. Although the passage primarily concerns the prophets in Jerusalem, the issues raised in this section concerned the wider community and had implications for the society.

There seems to be a direct correlation between the behaviour of people in Israel and the wellness of the land in which the people lived. The ethical or unethical behaviour of the people had a bearing on land conditions and in return, the land had an impact on the living conditions and the wellness of the people. Marlow has made some observations in this regard to Jeremiah 9:12. He remarks that, "The text moves seamlessly between two concepts that might, at first glance, seem to belong in two different categories: the desolation of the natural landscape, and the failure of Judah to keep God's law."3 This article departs from the assumption that this reciprocal relational reliance is the result of a particular worldview in which there exists interconnectedness of the divine, the people relating to this divine entity and the land allotted to them. I will explore this assumption by engaging Jeremiah 23:9-15 with particular emphasis on 23:10 and 15. The aim is also to bring the findings of the interaction with the text that functioned within a worldview that differs from that of modern-day readers, in dialogue with discussion on ecological matters confronting us.

As a first step, I will provide an overview of the structure and content of Jeremiah 23:9-15, followed by a brief discussion of the presumed worldview in the society of Jeremiah. The next step is a detailed discussion of Jeremiah 23:10 and 15 , which forms the core of this article. I will pay attention to the syntax, semantics and the literary features of the text and draw some conclusions based on the exegetical analysis. Lastly, I will raise some issues I deem relevant for the current ecological debate.

in Proverbs 3:19-20," Stellenbosch Theological Journal 4, No. 2 (2018): 579-594; Kivatsi J. Kavusa, "Ecological Hermeneutics and the Interpretation of Biblical Tests Yesterday, Today and Onwards: Critical Reflection and Assessment," Old Testament Essays 32, No. 1 (2019): 229-255.

2 Katherine M. Hayes, The Earth Mourns: Prophetic Metaphor and Oral Aesthetic, Academia Biblica 8 (Atlanta, Georgia: SBL, 2002).

3 Hilary Marlow, "Law and the Ruining of the Land: Deuteronomy and Jeremiah in Dialogue," Political Theology 14, No. 5 (2013): 650-51. 
308 Wessels, “The Earth Mourns," OTE 33/2 (2020): 306-322

\section{B THE STRUCTURE AND CONTENT OF JEREMIAH 23:9-15}

Jeremiah 23:9-15 is regarded as a defined passage that can be subdivided into 23:9-12 and 13-15. The reasoning for this is that there seems to be a progression in content with the second section making it more explicit who the people of concern to the prophet are. If the vocabulary of these two sections is taken into consideration, some keywords occur in both of them. The words are (verses 10 (twice) and 12), רָָָ (verses 10,11, 12 and 14), the root 10 and 14) and also the root (verses 11 and 15). Some progression is detected from verses 10-15 and some aspects that were vaguer became more explicit in the second section (12-15). Verse 15 serves a similar function as verse 12, namely, that of announcing a verdict. A similar structure is followed through the use of לִכ (15a) and (15d). If both the structure and the content are taken into consideration, a strong case can be made to read these two sections as a single unit.

As has been stated, the interest of this article is in the interconnectedness between the divine (Yahweh), the people of Judah and the land. The discussion to follow will, therefore, focus primarily on verse 10 and to a lesser degree on verse 15, but within the context of 23:9-15. These two mentioned verses in particular offer interesting insights in terms of ecological significance. Before discussing Jeremiah 23:10, a brief discussion of the worldview against which Jeremiah 23:9-15 should be read is offered.

\section{WORLDVIEW REFLECTED IN JEREMIAH}

When the whole passage of 23:9-15 is considered, several indicators alert the reader of a particular worldview reflected in this passage. Some of these indicators are the mention in verse 9 of Yahweh's holy words and by implication his holiness, the reference to the "house of Yahweh" in verse 10, which implies a cultic setting. Throughout the passage, mention is made of ethical transgressions such as the abuse of power (v.10), רָעָ (wickedness- verses 10, 11, 12 and 14), the root נאף (adultery- verses 10 and 14) and also the root (ungodliness/pollute verses 11 and 15). It all boils down to a strong focus on unethical behaviour against the background of Yahweh's holiness and the cult. To this should be added the reference to a curse (אָלָָ), most probably to be understood against the background of the covenant between Israel and Yahweh. Verse 10 with its strong emphasis on land (אר), is embedded in this worldview and provides a framework for the interpretation of verse 10 . 
I have previously discussed this understanding of the world in more detail in an article I wrote in $2017,{ }^{4}$ therefore I will only highlight a few aspects mentioned there.

Research has shown that the classification system consisting of the conceptual structures [HOLY/COMMON and PURE/IMPURE] defines how the Israelite society functioned. ${ }^{5}$ This also seems to apply to the discussion of Jeremiah 23:9-15. Latching onto this research, Van Wolde ${ }^{6}$ elaborated further on this classification system concerning how the Israelite society voiced their experience.

Van Wolde embarks on naming various cognitive domains and how these domains tie in with the categories of holiness, purity, impurity and idolatry. In terms of these domain categories, Yahweh is associated with the category holiness, the sanctuary (temple) with holiness, land to purity, people to impurity and idolatry to holiness/purity versus idolatry/impurity. ${ }^{7}$ These selected categories are all applicable to the interpretation of Jeremiah 23:9-15, which involves Yahweh, his word, land, idolatry, priests and prophets, temple and people. It should be noted that the passage under discussion entails moral impurity. The concept 'moral impurity' entails matters such as idolatry, sexual transgressions and bloodshed. Hrobon remarks that moral impurity is sin and causes separation from Yahweh, and even exile and death. ${ }^{8}$

If the above discussion is taken into account, then verse 23:9 should come to mind where the holiness of the Yahweh and his word were mentioned. It is clear that Yahweh is associated with the concept of "holiness." Goldingay 9 comments in this regard, "Yhwh makes the Israelites holy by giving them laws to obey, and the Israelites make themselves holy and become holy by obeying these laws." Yahweh has established a formal relationship with the people of Judah through a covenant. This relationship was first and foremost based on reciprocal fidelity and loyalty, but also certain obligations. These covenant obligations were formalised into stipulations to safeguard the relationship between Yahweh and his people. The curse mentioned in 23:10 should most

4 Wilhelm J. Wessels, "Rhetorical Language as a Device for Jeremiah's Authenticity Claims: His Rivalry with Adversaries," Journal for Semitics 26, No. 1 (2017): 165-67.

5 Cf. Jacob Milgrom, Leviticus 1-16: A New Translation with Introduction and Commentary, 1st ed., The Anchor Bible (New York: Doubleday, 1991), 719-25, 730-32.

6 Ellen J. Van Wolde, Reframing Biblical Studies: When Language and Text Meet Culture, Cognition, and Context (Winona Lake, Indiana: Eisenbrauns, 2009), 208-211.

$7 \quad$ Van Wolde, 209.

8 Bohdan Hrobon, Ethical Dimension of Cult in the Book of Isaiah, Beihefte Zur Zeitschrift Für Die Alttestamentliche Wissenschaft 418 (Berlin, New York: De Gruyter, 2010), 19.

9 John Goldingay, Israel's Life, Old Testament Theology 3 (Downers Grove, Illinois: InterVarsity Press, 2009), 609. 
probably be related to the covenant and the obligations associated with the covenant. The prophets of Israel and Judah, and in particular Jeremiah, condemned the worship of foreign gods. Idol worship was viewed as a grave form of infidelity and a breach of trust. The passage in Jeremiah 23:9-15 clearly shows that for the prophet, reflecting the worldview discussed above, with the holiness of Yahweh and his word as key elements, moral impurity was intolerable. It could only have disastrous consequences for the people and the land. Joosten ${ }^{10}$ has the following to say:

The holy presence of Yahweh in the midst of the Israelites will not tolerate impurity or unholy behaviour of any kind. The transgressions of the commandments must be punished swiftly, because the impurity generated by the transgressions of the Israelites will be projected on to the sanctuary, which in this way will be defiled. The final effect will be the withdrawal of the divinity from his earthly dwelling, for his holiness cannot coexist with impurity.

The discussion offered above is of relevance for the interpretation and understanding of Jeremiah 23:10.

\section{ANALYSIS OF JEREMIAH 23:10 AND 15}

10a For the land is full of adulterers;

$10 \mathrm{~b}$ because of the curse the land mourns,

10c and the pastures of the wilderness are dried up.

10d Their course is evil,

10e and their might is not right.

15a Therefore, thus says the LORD of hosts concerning the prophets:

$15 \mathrm{~b} \quad$ "Behold, I am going to make them eat wormwood,

15c and give them poisoned water to drink;

$15 \mathrm{~d}$ for from the prophets of Jerusalem ungodliness has spread throughout the land."

Jeremiah10a and 10d-e correspond, while 10b-10c describes the effects on the earth and the land because of the adulterers' evil ways and might that is not right. The syntax allows for the perspective of the earth to be seen, because the consequences of the actions of the adulterers for the earth are presented as a temporal process.

In clause $10 \mathrm{a}$, the land takes centre stage. It is clear from the context that a specified land is referred to here as is indicated by the definite article to Since the context concerns Yahweh, the prophet and the book of Jeremiah placed

10 Jan Joosten, People and Land in the Holiness Code: An Exegetical Study of the Ideational Framework of the Law in Leviticus 17-25, Vetus Testamentum Supplement 67 (Leiden: Brill, 1996), 199. 
in the historical context before the Babylonian exile, land here implies the land of Judah and in a broader context, the land of Israel. If the classification of Douglas $^{11}$ is again considered, the spatial category of land regarding Israel is meant here. It does not imply land as earth, but land as a gift from Yahweh to Judah. Van Wolde ${ }^{12}$ as discussed assigns land to the central semantic concept of "purity."

Clause 10a states that the land is full of adulterers. The Qal perfect verb מלא denotes a reality of great consequence. The Piel participle masculine plural of the verb נאף, indicating intensification, serves the function of a noun referring to people who have committed adultery. At this stage, it is not clear from the immediate context who these so-called adulterers are and what the reference to adultery implies.

The Piel participle plural occurs five times in the Old Testament. In Psalm 50:18, it is used in the sense of marital infidelity and in Jeremiah 9:1 in the context of people who are branded as traitors. In this Jeremiah incidence, it seems that the reference to adultery leans more towards the idea of disloyalty and not in the sense of sexual infidelity.

The context of 8:18-9:3 makes it clear that the people of Judah are regarded as unfaithful because they worship useless idols. What is interesting here is that, similar to 23:9, the speaker (the prophet) in this context is also experiencing strong emotions and bodily imagery are used to depict these strong emotions. In both instances, the prophets (the speakers) label the people "adulterers" for what they have been doing.

It is further used in Jeremiah 23:10 and Hosea 7:4. The last reference in Hosea again does not seem to have any sexual overtones, but describes the continued wicked behaviour of the king's advisers before Yahweh. In Malachi $3: 5$, the reference is to people who are unfaithful in marriage. There is a Piel participle singular incidence of נאף In Isaiah 57:3 where there seems to be both the idea of infidelity in relationship with Yahweh, but also of sexual overtones relating to idol worship practices. In Proverbs 30:20, the Piel participle of this verb refers to an adulteress as is the case in Hosea 3:1 and Ezekiel 16:32. The verb נאף is used in the Piel in Jeremiah 3:8 and 29:23 and the Qal in 3:9; 5:7; 7:9 and 23:14.

The Qal form of the verb "to commit adultery" is used in Jeremiah 5:7 as a reference to the worship of false gods and in 7:9, to the worship of Baal and other gods. This also applies to Jeremiah 3:8 (Piel form of the verb as in 23:10), where the unfaithfulness of Israel and Judah refers to the worship of idols made of stone and wood. It is important to note that although the concept of "covenant"

11 Cf. Van Wolde, Reframing Biblical Studies, 208.

12 Van Wolde, Reframing Biblical Studies, 211. 
does not occur in many instances in the book of Jeremiah, the language and imagery in the book reflect the covenant relationship. An example of this is Jeremiah 2 where the relationship with Yahweh is depicted as a marriage and this image is continued in chapter three where we have the reference to adultery. ${ }^{13}$ It, therefore, seems that when adultery is mentioned, that the covenant should be seen as the context of such utterances.

It is difficult to arrive at any conclusive understanding of the meaning of this verb in Jeremiah, because it can refer to religious infidelity, political alliances, sexual transgression and idol cultic practices. The metaphorical uses of this verb make a clear determination of the meaning difficult. It is perhaps only Jeremiah 5:8 and 29:23 that have sexual infidelity overtones.

The word "adultery" literally means to be unfaithful in the context of a marital or similar relationship between a party in such a relationship and another person not part of the relationship. Adultery is usually regarded to be committed by a man with another man's wife. The major concern regarding adultery is a matter of infidelity. By committing adultery with another man's wife, the sacred right of that husband is violated. ${ }^{14}$ Adultery belongs to the field of words associated with moral transgressions. Coppes interprets the root to mean "sexual intercourse with the wife or betrothed of another man." 15 Freedman and Willoughby ${ }^{16}$ have argued that the use of the term "adultery" by the prophets has the Decalogue as background. They base their assumption on the similarity in wording with the Decalogue. When the prophets use the concept of "adultery," they imply a breach or violation of the covenant. Freedman and Willoughby further argue that besides the breach of the covenant, adultery can also imply infidelity to Yahweh, when idols are worshipped and idolatrous cultic practices are pursued. It should also be noted that the relationship of the people of Israel and Judah with Yahweh is sometimes depicted by the prophets Hosea and Jeremiah as a marriage. Disloyalty to Yahweh in this relationship is then labelled as adultery.

With the limited information given by the immediate context of the clause in $10 \mathrm{a}$, all that can be concluded is that the land of Israel has many people who have committed acts of infidelity similar to marital infidelity. However, the

13 Cf. Walter Brueggemann, A Commentary on Jeremiah: Exile and Homecoming (Grand Rapids, Michigan: Eerdmans, 1998), 32-33; 42-43.

14 David N. Freedman \& B. E. Willoughby, "נָָארָ Nā'ap," in Theological Dictionary of the Old Testament, ed. G. Johannes Botterweck, Helmer Ringgren, and Heinz-Joseph Fabry, Vol. IX (Grand Rapids, Michigan: Eerdmans, 1998), 114-15.

15 Leonard J. Coppes, "נָָָּ Commit Adultery," in Theological Wordbook of the Old Testament, ed. R. Laird Harris, Gleason L. Archer Jr., and Bruce K. Waltke (Chicago, Illinois: Moody, 1980), 542.

16 Freedman and Willoughby, "נָָאָָ Nā'ap," 115-17. 
broader context of the passage (23:9-15) might bring more clarity as to how this concept should be understood.

Because of the syntax, it is argued that $10 \mathrm{~b}$ should be understood as follows: because adulterers filled the land, the result was a curse on the land. The noun without a preposition appears only once in the book of Jeremiah in $23: 10$. The noun has the meaning of an oath or a curse. ${ }^{17}$ In the context of Jeremiah 23:10, it clearly has a negative connotation and the meaning of curse seems appropriate (cf. also Jr 29:18; 42:18 and 44:12 where the noun is used with the preposition ? and has the meaning of a curse). In Genesis 26:28 the noun אָלָ is associated with the making of a covenant and then oath as meaning is applicable. In Ezekiel 16:59; 17:18, the breaking of the covenant is seen as an act of despising the oath that formed part of the covenant agreement. An interesting correspondence is observed between Jeremiah 23:10 and Isaiah 24:46. What is important is that covenant and curse are directly related in this passage and the context is also that of the land suffering because of a curse. It is also important to note that the verb wis used in this passage similar to Jeremiah 23:10.

The noun wָלָ is also associated with legal matters where someone has to testify and make a solemn statement (cf. Lev 5:1; $1 \mathrm{Kgs} \mathrm{8:31;} \mathrm{Ps} \mathrm{10:7} \mathrm{and} \mathrm{Prov}$ $29: 24)$. What seems to be emanating from the above is that oath and covenant go together and when the covenant is disregarded the oath results in a curse. ${ }^{18}$ Keller ${ }^{19}$ indicates that, in essence, the noun אָדָ is a legal term belonging to the establishment of a solemn agreement between parties in the form of a covenant with a curse safeguarding this agreement. In Deuteronomy 29:9-28, which deals with the covenant between Yahweh and his people, the noun surfaces several times to indicate that there are several sanctions (plural of אָלָה) accompanying the covenant agreement. These sanctions have the function of safeguarding the covenant. $^{20}$ They take on the form of curses when people have acted in bad faith by breaking the covenant agreement. It is perhaps also what is implied in Jeremiah 23:10 except that a direct reference to "covenant" is lacking.

The designated land of Judah is used in combination with the Qal perfect feminine singular form of the verb אבָָל expressing an action of mourning. The land is personified by an act of mourning. The same form of the verb אָבָ appears in Isaiah 24:4 with the land as subject and in combination with the verb נבל,

17 David J. A. Clines, The Dictionary of Classical Hebrew, ed. David J. A. Clines, Vol. 1 (Sheffield: Sheffield Academic, 1993), 272.

18 Cf. J. B. Scott, "אָלָָ," in Theological Wordbook of the Old Testament, ed. R. Laird Harris, Gleason L Archer Jr., and Bruce K. Waltke (Chicago, Illinois: Moody, 1980), 45.

19 C. A. Keller, "אָלָה 'ālā' Verfluchung," in Theologisches Handwörterbuch zum Alten Testament: 'Āb - mātaj Band 1, ed. Ernst Jenni and Claus Westermann, Vol. I (München: Kaiser Verlag, 1971), 150-152.

20 Keller, 152. 
which has a synonymous meaning, namely, "withers/languishes." However, this verse also uses the Pulal perfect verb אמל (twice), which is also synonymous in meaning to be weak/to languish. The broader context of Isaiah 24:4-6 shows an even greater resemblance with Jeremiah 23:10b. Besides the verb אבָבר , the noun אָלָָ also occurs in verse 6. However, what is further significant is the reference to the covenant in verse 5 . The correspondence does not end here; in 23:11, the verb חנף appears that also occurs in Isaiah 24:5. The apocalyptic text in Isaiah 24 is late and as Brueggemann ${ }^{21}$ proposes, perhaps the latest of the texts in the Isaiah collection. The text is in all probability later than the reference in Jeremiah 23:10. The important point, however, is the withering of the land due to a curse which is related to the breaking of the covenant.

In Jeremiah $12: 11$, there is again a reference to the land that mourns because some leaders have ruined the land and left it desolate. The same form of the verb in is used in Jeremiah 14:2 in a context of a drought that impacts on the land, but in this instance, it is the people of Judah that mourn and not the land. In Joel 1:10, we again find the same form of the verb אָבָ, but the reference is not to the land but the ground (אָדָדָָה). It is also interesting to note that the Pulal perfect verb אמל appears in the context of this verse.

From the preceding discussion, it seems reasonable to conclude that the use of the Qal perfect feminine singular form of the verb is associated with circumstances in which the land suffers a state of drought because of what people did and because of Yahweh's response to what they have done. The land mourns because of the state in which it is due to the negative deeds people have committed. The metaphorical use of land that mourns has the implied meaning that the land has wilted.

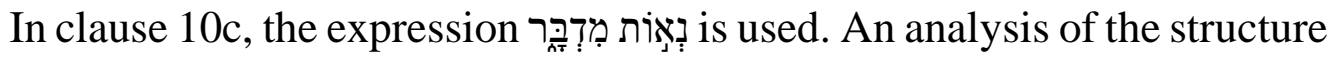

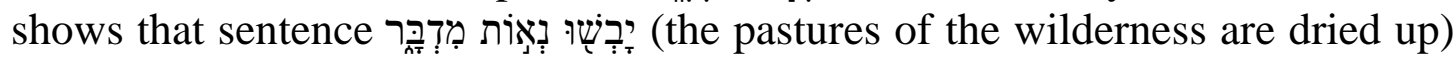
forms a synonymous parallelism with אָבְלָה דָאָרָרץ (the land mourns). It also appears in Psalm 65:13; Jeremiah 9:9; Joel 1:19 and 2:22 and is translated in all instances as "pastures of the wilderness." The fact that "wilderness" is used in combination with "pasture" implies that a section of the land is referred to where some form of grazing is found and where animals can be found or were found once (cf. Ps 65:13-14; Jr 9:9 [animals have left]; Jl 1:19 and 2:22). According to Talmon, the expression "pastures of the wilderness" is a technical term referring to land suitable as pasture for livestock "surrounding a permanent or semipermanent pastoral settlement $n \bar{a} w e h .$. or adjacent to villages or towns." 22

21 Walter Brueggemann, An Introduction to the Old Testament: The Canon and Christian Imagination (Louisville, Kentucky: Westminster John Knox, 2003), 164.

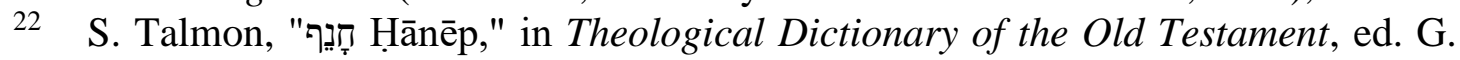
Johannes Botterweck, Helmer Ringgren, and Heinz-Joseph Fabry, Vol. VIII (Grand Rapids, Michigan: Eerdmans, 1997), 91. 
In the light of the above information, it is safe to say that the curse referred to in verse 10 will result in drought affecting both people and all forms of livelihood and livestock in Judah with a devastating effect. It will have an impact on people in the city, rural communities, herdsmen and nomads. The meaning of

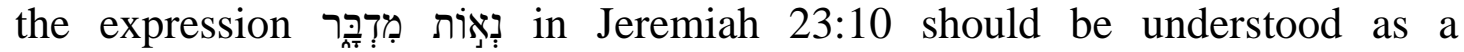
geographical indicator as far as its semantic field is concerned.

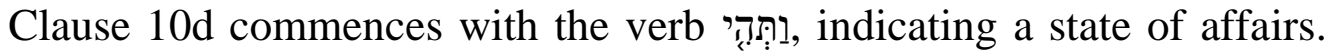
This verb relates to both $10 \mathrm{~d}$ and $10 \mathrm{e}$ which form part of a parallelism. In clause 10d, the noun מְרוּצָה follows on the verb דֶרוּצָה derivative for the verb רוץ, which has the basic meaning of running rapidly. ${ }^{23}$ There are only three occurrences of the noun in 2 Samuel 18:27; Jeremiah 8:6 and 23:10. In Samuel, it refers to a person's style of running and in Jeremiah 8:6, where the comparison is with a horse running, the emphasis is on the speed with which the people of Israel turn away from Yahweh. The use in Jeremiah 23:10 is figurative and "denotes a way of life, the manner in which a person lives from a moral perspective." 24 In clause $10 \mathrm{~d}$ a construct form indicates that the running or style of unidentified adulterers is evil. If the basic meaning of the verb "to run rapidly" is considered, it might even show that there is a sense of urgency in the way they engage in wrong conduct. This means that their way of doing is defined as evil (רָעָה). What this means exactly is unclear if taken in isolation, but as Maiberger has indicated, it has to do with moral wrong conduct. The ensuing discussion will shed more light on what is in mind here.

The concept רָָָה appears 787 times in the Old Testament. It is used in many contexts with meanings varying from "bad," "evil," "wickedness" and "disaster." It is used in Jeremiah no fewer than 146 times. Dohmen ${ }^{25}$ regards this frequent use as being due to Jeremiah's many prophecies of judgment and the Deuteronomistic redactional activity in the book. In many instances, Jeremiah describes the actions of the people of Judah as רִָָּ (sin, bad, evil or wickedness), which then results in Yahweh responding in judgment also defined as (disaster). About sin, Dohmen ${ }^{26}$ says, 'both 'deviant behavior' and reluctance to repent are qualified as evil - especially those actions and attitudes that are connected intimately with social and religious reality." In many instances, unacceptable actions concerning religious and cultic practices such as apostasy,

23 P. Maiberger, "רוּץ Rûș," in Theological Dictionary of the Old Testament, ed. G. Johannes Botterweck, Helmer Ringgren, and Heinz-Joseph Fabry, Vol. XIII (Grand Rapids, Michigan: Eerdmans, 2004), 417.

24 Maiberger, 421-22.

25 C. Dohmen, "רָעָּה Rā'â," in Theological Dictionary of the Old Testament, ed. G. Johannes Botterweck, Helmer

Ringgren, and Heinz-Joseph Fabry, Vol. XIII (Grand Rapids, Michigan: Eerdmans, 2004), 567.

26 Dohmen, 584. 
disloyalty, disobedience and a rebellious attitude towards Yahweh are expressed

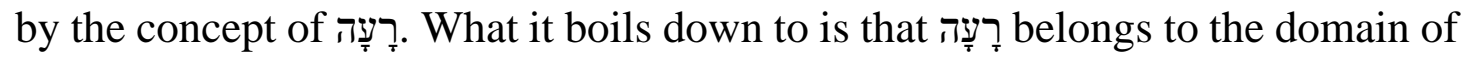
moral/ethical matters when it concerns the actions of human beings. ${ }^{27}$

When looking at clause $10 \mathrm{e}$ in context, the syntax shows a synthetic parallelism with 10d, which implies that 10e either complements or completes $10 \mathrm{~d}$ or helps to clarify the meaning of the first component of the parallelism. In

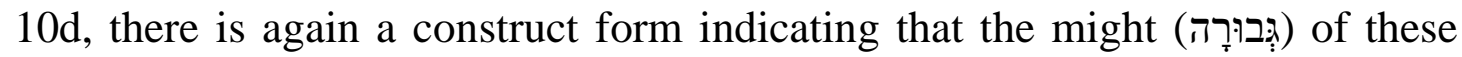
adulterers is not right. The parallelism underscores the meaning of the expression "their running/conduct is evil" by relating it to the incorrect use or abuse of might.

The concept of מִּבוּרָה has many different meanings. Not only can it refer to physical strength, but also powerful people in a society. It is often associated with military power. ${ }^{28}$ In the context of Jeremiah 23:10 or the immediate context, there is no clear indication that the "wrongness" of their power should be understood in terms of physical abuse. It seems that power abuse takes place within the field of moral transgressions. Their conduct is characterised as morally evil (רָעָׁה), and in terms of the synthetic parallelism, the way the people exercise their might or power should be understood within the framework of moral abuses. Kosmala ${ }^{29}$ has argued strongly for relating "might" in the spiritual sense of it to all that is associated with wisdom such as trust, fear of God and spiritual strength. Against the backdrop of Jeremiah 9:22, he observes, "The fear of God, which involves obedience to his commandments, encompasses a group of spiritual characteristics that show man the right way." 30 The meaning of "might" in 23:10 should perhaps be searched for in line with Kosmala's line of argumentation. Instead of displaying moral strength and soundness of judgment, what they exercise is not right. Their strength lacks honesty (לאיכָ). In the context of 23:10 and this reference (10e) being used in parallelism with 10e (their conduct is evil), it simply means that the power of the "adulterers," unidentified at this stage, is corrupt.

From the broader context of $23: 9-15$, it becomes clear that this is a reference to the prophets of Jerusalem who are seen as people committing adultery and whose conduct is branded as deceitful (cf. 23:14). The meaning of לאיכָ should be determined in the semantic field of unethical behaviour.

27 Cf. also Albert H. Kamp, Inner Worlds: A Cognitive-Linguistic Approach to the Book of Jonah, Biblical Interpretation Series 68 (Boston: Brill, 2004), 160.

28 H. Kosmala, "הֶּוּרָ Gebhûrāh," in Theological Dictionary of the Old Testament, ed. G. Johannes Botterweck, Helmer Ringgren, and Heinz-Joseph Fabry, Vol. II (Grand Rapids, Michigan: Eerdmans, 1975), 369.

29 Kosmala, 371-72.

30 Kosmala, 372. 
To summarise, what does Jeremiah 23:10 communicate? According to the speaker in verse 10 , the land mourns because ${ }^{31}$ of the curse. The result of the curse is that the pastures of the wilderness ${ }^{32}$ have dried up. The expression "the land mourns" means that the land is wilting. In a synonymous parallelism (10c) it is further noted that because of the curse, the "pastures of the wilderness have dried up." This last clause is a reference to geographical areas adjacent to the villages and towns suitable for semi-nomadic livestock and sedentary farmers. The curse on the land will affect people in the cities and rural areas. What becomes clear in this verse, is the relationship between disobedience to Yahweh and his covenant and the disastrous consequences for both the land and the people. ${ }^{33}$ Brueggemann $^{34}$ offers an insightful discussion of the Creation as Yahweh's partner. He refers to the freedom of Yahweh as Creator, but also points out that, in Israel's rhetoric, Yahweh's freedom is never free from moral conditions mandated by the covenant stipulations. ${ }^{35}$ In Jeremiah 23:10, Yahweh's curse on the land results in drought and mourning. This all happens because of the disregard of the moral stipulations of the covenant law. What has occurred is aptly summed up by Fretheim when he concludes that, "Moral order adversely affects cosmic order; human sin has had a deeply negative effect upon the environment (just the opposite of claims made for Baal worship on the land's fertility)." 36

Verse 10 refers to unidentified adulterers and states that, "their running has been evil, and their might is not right." Although the prophets are not mentioned explicitly in this verse, the context of 23:9-15 makes it clear that they are the people Jeremiah has in mind. They occupy positions in society that allow them to influence people from a religious perspective. ${ }^{37}$ These opposition prophets had power because they were part of the official structure of the ruling party in Judah.

An important connection is made between adultery, the evil conduct and the unethical power, and a curse on the land. If the argument is correct, that the

31 Cf. Jr 4:8, 12:4, 14:2, 4.

32 Cf. Ps 65:13; Jr 9:9; J1 1:19, 2:22.

33 Cf. Douglas R. Jones, Jeremiah, New Century Bible Commentary (Grand Rapids, Michigan: Eerdmans, 1992), 305.

34 Walter Brueggemann, Theology of the Old Testament: Testimony, Dispute, Advocacy (Minneapolis, Minnesota: Fortress Press, 1997), 528-51.

35 Brueggemann, 543.

36 Terence E. Fretheim, Jeremiah, Smyth \& Helwys Bible Commentary (Macon, Georgia: Smith \& Helwys, 2002), 33. Cf. also Fretheim's (2002:100) discussion of moral order and cosmic order, where he discusses the interconnectedness of human behaviour and the cosmic consequences. In this regard, read also Fretheim (2002:3033; also 34-35 - sin and judgment).

37 Cf. F. B. Jr Huey, Jeremiah, Lamentations, The New American Commentary 16 (Nashville, Tennessee: Broadman, 1993), 214. 
covenant forms the background for an understanding of what is described in verse 10, then the evil conduct most probably has to do with the worship of other gods besides Yahweh. ${ }^{38}$ It seems that powerful people throughout the land took the lead in committing infidelity concerning Yahweh and violating the covenant. In a discussion of Jeremiah 2:1-4:4, a passage related to $23: 9-15$, Yates ${ }^{39}$ makes the following observation:

Israel's sin has turned the "fertile land" (2:7) into a barren wasteland (2:15), like the "desert" from which Yahweh had delivered Israel (2:6). The interplay of 'land' and 'desert' most effectively demonstrates the futility of Israel's trust in fertility gods like Baal. If they had remained loyal to Yahweh, they could have enjoyed a "fertile land" (2:7) instead they trusted in Baal and ended up with a "desert."

Jeremiah 23:15 also relates to what is communicated in verse 10. In 23:15, the prophets are blamed for spreading what is categorised as profane (ungodliness) throughout the land and, in so doing, polluting the land. The worship of foreign gods is probably meant here. Interestingly, the land is again mentioned here in verse 15 as was the case in verse 10 . The moral corruption for which the prophets of Jerusalem are blamed has spread through the entire land. If read together then, perhaps, not only the moral aspect of godlessness should be envisaged, but also the pollution of the land as it relates to drought (pestilence). ${ }^{40}$ This would tie in with the idea of infertility of the land as a judgment on the adulterous practices of the prophets. ${ }^{41}$ Infertility of the land would imply no growth, no produce and therefore no food. This would lead to starvation and death. The implied ritual of eating and drinking showed the prophets to be guilty of moral misconduct, therefore the resulting blame for the pollution (defilement) of the whole land. The eating and drinking of the poisonous substances of wormwood and poisoned water, both elements emanating from the land, will, in the long run, be the "revenge" of the land in infertility and therefore no produce from the land.

From the discussion offered, it seems fair to conclude that there exists interconnectedness between the divine, the people relating to this divine entity and the land allotted to them. The holiness of Yahweh required appropriate ethical behaviour. The worldview discussed revealed that the behaviour of

38 Cf. R. L. Honeycutt, "Jeremiah 23:9-40," Review and Expositor 86 (1989): 58485.

39 Gary E. Yates, "The Call for the Unfaithful Wife to Return: The Rhetoric of Prophetic Appeal in Jeremiah 2:1-4:4" (Evangelical Theological Society Annual Meeting, San Diego, California: Liberty University Press, 2007), 13.

40 William McKane, Introduction and Commentary on Jeremiah I-XXV, Vol. 1, International Critical Commentary (Edinburgh: T \& T Clark, 1986), 576.

41 Cf. Van Wolde, Reframing Biblical Studies, 228-233. 
people in Israel and the wellness of the land in which the people lived were interrelated.

\section{E RELEVANCE OF JEREMIAH 23:10 AND 15 TO THE ECOLOGICAL DEBATE}

A few concluding remarks on the relevance of the ecological debate seems appropriate. First and foremost it should be realised that the Jeremiah text is a religious text and therefore displaying a worldview that reflects this. The research has revealed that there is an interconnectedness between the divine, humans and the land. The unethical behaviour of religious leaders and as a consequence of their influence on the ordinary people, when they acted similarly, resulted in Yahweh taking action against them with consequences for the land. People who share this biblical worldview would be inclined to interpret negative experiences such as drought as a consequence of disobedience to Yahweh and his requirements.

People who wish to present a biblical theology 42 often apply dogmatic constructs $^{43}$ as a way of looking at life and creation. They would find the schematic approach of harmonious living-disobedience-punishment-redemption a handy model for approaching the ecological dilemma of Jeremiah 23:10 and 15. This would imply that life, as was expected by Yahweh, was disrupted by unethical behaviour, interpreted as disloyalty and disobedience, resulting in the punishment of a curse on the land. To re-establish the equilibrium, people needed to atone for their transgressions for Yahweh to restore the state of the land and harmoniously. This view of life in relationship with Yahweh would have much in common with the worldview revealed by the text in Jeremiah in that punishment is the expected result for disloyalty and disobedience to Yahweh. The broken relationship with Yahweh, resulting in punishment, will affect all aspects of human existence, also the state of the land.

Not all people who relate their existence to a divine being, as reflected in the biblical text, would necessarily similarly reflect on Jeremiah 23:10 and 15 as discussed. Many people have a keen interest in the biblical texts and respect them as sacred texts. Such people take the view that emanates from a study of the text seriously, but understand them as expressions of particular worldviews. These

\footnotetext{
42 An example in this regard is the work of Douglas J. Moo and Jonathan A. Moo, Creation Care: A Biblical Theology of the Natural World (Grand Rapids, MI: Zondervan, 2018).

43 Ernst M. Conradie, "The Road towards an Ecological Biblical and Theological Hermeneutics," Scriptura 93 (2006): 306 uses the term "doctrinal constructs" which he elaborates on by saying: "Doctrinal constructs are not only employed to find similarities but to construct similarities, to make things similar, if necessary." This can be a constructive organising principle, but one should care not to force matters into created categories.
} 
worldviews should as far as possible be understood as stemming from a particular socio-historical context. Such an approach to the biblical text would imply an acknowledgement of a distance between the text and the world of the text and that of the reader and interpreter of the text. ${ }^{44}$ It is highly likely that a current-day interpreter of the text would hold a different worldview from the view reflected by the text in Jeremiah, or for that matter the biblical text as a whole. The consequence of this is that, although the text is treated with the necessary respect as a sacred text, the biblical text would not necessarily be regarded as prescriptive for a debate on the ecological matters.

For those in society who have no regard for the biblical text, I will argue that it still has relevance to take note of the issue the Jeremiah text brings to the table concerning the relationship between human actions and the consequences for nature, in particular the land. But also the reciprocal consequences the deleterious state of the land and nature has for and on humans.

Although we have different worldviews, we can still interact with the text - be surprised by the text, challenged by it, at times be abhorred - but still, this engagement with the text can cause us to reflect on our views and ideas and their validity. By engaging a text, you become part of a conversation where there is at times an agreement but at times also disagreement. And through engagement, we grow and learn a lot about ourselves. Whether we have a pre-scientific or scientific worldview, the fact remains, we are interconnected with the land and nature. Our carelessness and unethical behaviour will have consequences for our environment, and our environment due to our negligence or because of the natural consequences will impact our existence.

\section{BIBLIOGRAPHY}

Ademiluka, Solomon Olusola. "An Ecological Interpretation of Leviticus 11-15 in an African (Nigerian) Context," Old Testament Essays 22, No. 3 (2009): 525-534.

Brueggemann, Walter. Theology of the Old Testament: Testimony, Dispute, Advocacy. Minneapolis, Minnesota: Fortress Press, 1997.

- A Commentary on Jeremiah: Exile and Homecoming. Grand Rapids, Michigan: Eerdmans, 1998.

-An Introduction to the Old Testament: The Canon and Christian Imagination. Louisville, Kentucky: Westminster John Knox, 2003.

Divine Presence amid Violence: Contextualizing the Book of Joshua (Eugene, Oregon: Cascade Books, 2009.

Clines, David J. A. The Dictionary of Classical Hebrew. Edited by David J. A. Clines. Vol. 1. Sheffield: Sheffield Academic, 1993.

44 Cf. Kavusa, Ecological Hermeneutics, 250-251 argues that the 'otherness of biblical texts' should be recognised. See also Walter Brueggemann, Divine Presence amid Violence: Contextualizing the Book of Joshua (Eugene, Ore: Cascade Books, 2009), ix-xii, 3-10 who offers a well-balanced view of interpretation for modern readers of biblical texts. 
Conradie, Ernest M. "The Road towards an Ecological Biblical and Theological Hermeneutics," Scriptura 93 (2006): 305-314. https://doi.org/10.7833/93-0-1371.

Coppes, Leonard J. "נָָָָר Commit Adultery." Pages 542-543 in Theological Wordbook of the Old Testament, edited by R. Laird Harris, Gleason L Archer Jr., and Bruce K. Waltke. Chicago, Illinois: Moody, 1980.

Dohmen, C. "רָעָָ Rā'â." Pages 560-587 in Theological Dictionary of the Old Testament, XIII, edited by G. Johannes Botterweck, Helmer Ringgren, and Heinz-Joseph Fabry. Grand Rapids, Michigan: Eerdmans, 2004.

Freedman, David N, and B. E. Willoughby. "נָָָרָ Nā'ap." Pages 113-118 in Theological Dictionary of the Old Testament, edited by G. Johannes Botterweck, Helmer Ringgren, and Heinz-Joseph Fabry, IX. Grand Rapids, Michigan: Eerdmans, 1998.

Fretheim, Terence E. Jeremiah. Smyth \& Helwys Bible Commentary. Macon, Georgia: Smith \& Helwys, 2002.

Goldingay, John. Israel's Life. Old Testament Theology 3. Downers Grove, Illinois: InterVarsity Press, 2009.

Hayes, Katherine M. The Earth Mourns: Prophetic Metaphor and Oral Aesthetic. Academia Biblica 8. Atlanta, Georgia: SBL, 2002.

Honeycutt, R L. 'Jeremiah 23:9-40.' Review and Expositor 86 (1989): 583-94.

Hrobon, Bohdan. Ethical Dimension of Cult in the Book of Isaiah. Beihefte Zur Zeitschrift Für Die Alttestamentliche Wissenschaft 418. Berlin; New York: De Gruyter, 2010.

Huey, F. B. Jr. Jeremiah, Lamentations. The New American Commentary 16. Nashville, Tennessee: Broadman, 1993.

Jones, Douglas R. Jeremiah. New Century Bible Commentary. Grand Rapids, Michigan: Eerdmans, 1992.

Joosten, J. People and Land in the Holiness Code: An Exegetical Study of the Ideational Framework of the Law in Leviticus 17-25. Vetus Testamentum Supplement 67. Leiden: Brill, 1996. https://doi.org/10.1163/9789004275911_002.

Kamp, Albert H. Inner Worlds: A Cognitive-Linguistic Approach to the Book of Jonah. Biblical Interpretation Series 68. Boston: Brill, 2004.

Kavusa, Kivatsi, J. "Social Disorder and the Trauma of the Earth Community: Reading Hosea 4:1-3 in Light of Today's Crises," Old Testament Essays 29, No. 3 (2016): 481-501. https://doi.org/10.17159/2312-3621/2016/v29n3a8.

Kavusa, Kivatsi, J. "An Eco-Theological interpretation of Proverbs 5:15-20 in the light of water crises experienced in present-day Africa," Old Testament Essays 30, No. 3 (2017): 707-724. https://doi.org/10.17159/2312-3621/2017/v30n3a10.

Kavusa, Kivatsi, J. "Creation made into חָכָּמָָה : The eco-theological appraisal of the intrinsic worth of nature in Proverbs 3:19-20," Stellenbosch Theological Journal 4, No. 2 (2018): 579-594.

Kavusa, Kivatsi, J. "Ecological Hermeneutics and the Interpretation of Biblical Tests Yesterday, Today and Onwards: Critical Reflection and Assessment." Old Testament Essays 32, No. 1 (2019): 229-255. https://doi.org/10.17159/23123621/2019/v32n1a13.

Keller, C A. "אָָָָ 'ālā' Verfluchung." Pages 589-609 in Theologisches Handwörterbuch zum Alten Testament: 'Āb - mātaj Band 1, edited by Ernst Jenni and Claus Westermann. München: Kaiser Verlag, 1971. 


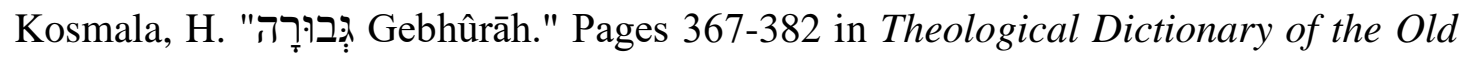
Testament, II, edited by G. Johannes Botterweck, Helmer Ringgren, and HeinzJoseph Fabry. Grand Rapids, Michigan: Eerdmans, 1975.

Maiberger, P. "רוּץ Rûs.." Pages 416-422 in Theological Dictionary of the Old Testament, XIII, edited by G. Johannes Botterweck, Helmer Ringgren, and Heinz-Joseph Fabry. Grand Rapids, Michigan: Eerdmans, 2004.

Marlow, Hilary. "Law and the Ruining of the Land: Deuteronomy and Jeremiah in Dialogue." Political Theology 14, No. 5 (n.d.): 650-60. https://doi.org/10.1179/1462317x13z.00000000042.

McKane, William. Introduction and Commentary on Jeremiah I -XXV. Vol. 1. International Critical Commentary. Edinburgh: T \& T Clark, 1986.

Milgrom, Jacob. Leviticus 1-16: A New Translation with Introduction and Commentary. 1st ed. The Anchor Bible. New York: Doubleday, 1991.

Moo, Douglas J., and Jonathan A. Moo. Creation Care: A Biblical Theology of the Natural World. Grand Rapids, Michigan: Zondervan, 2018.

Scott, J B. "אָדָדה." Page 45 in Theological Wordbook of the Old Testament, edited by R. Laird Harris, Gleason L. Archer Jr., and Bruce K. Waltke, 45. Chicago, Illinois: Moody, 1980.

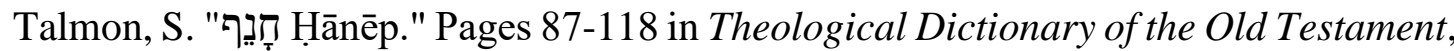
VIII, edited by G. Johannes Botterweck, Helmer Ringgren, and Heinz-Joseph Fabry. Grand Rapids, Michigan: Eerdmans, 1997.

Van Heerden, Schalk W. "Taking Stock of Old Testament Scholarship on Environmental Issues in South Africa: Main Contributions and Challenges," Old Testament Essays 22, No. 3 (2009): 695-718. https://doi.org/10.17159/23123621/2017/v30n2a16.

Van Heerden, Schalk W. "Shades of Green - Grey? Towards an Ecological Interpretation of Jonah 4:6-11," Old Testament Essays 30, No. 2 (2017): 459-477.

Van Wolde, Ellen J. Reframing Biblical Studies: When Language and Text Meet Culture, Cognition, and Context. Winona Lake, Indiana: Eisenbrauns, 2009.

Wessels, Wilhelm J. "Rhetorical Language as a Device for Jeremiah's Authenticity Claims: His Rivalry with Adversaries." Journal for Semitics 26, No. 1 (2017): 158-76. https://doi.org/10.25159/1013-8471/3111.

Yates, Gary E. "The Call for the Unfaithful Wife to Return: The Rhetoric of Prophetic Appeal in Jeremiah 2:1-4:4," 1-31. San Diego, California: Liberty University Press, 2007.

Professor Wilhelm J. Wessels (Professor Emeritus), Research Fellow of the Department Biblical and Ancient Studies, University of South Africa. Email: wessewj@telkomsa.net. ORCID: https://orcid.org/0000-0002-2164-9592. 